\title{
KAN DIE MILITÊRE STRATEEG BAAT VIND BY BEMARKING?
}

\author{
DEUR PROFESSOR J.A. BENNETT* \\ PROFESSOR C. BOSHOFF
}

\section{INLEIDING}

Bemarking en bemarkingsdenke vind hul oorsprong by die problematiek van dieekonomiteitsbeginsel soos gesien uit die perspektief van wins-georiënteerde ondernemings wat fisiese produkte vervaardig. Dié aanvanklike eng beskouing het egter nie lank onbevraagteken gebly nie. Sommige bemarkers het die rol en toepassing van bemarking in breër konteks beskou. Philip Kotler en Syd Levey (1969) was van die eerstes wat van die eng 'fisiese produk vir wins' benadering weggebreek het deur te argumenteer dat enige onderneming wat funksioneer om menslike behoeftes te bevredig eintlik bemark. Dat die onderneming ter wille van wins funksioneer is nie as relevant beskou nie. Kotler \& Levey (1969) het in die lig hiervan gepleit dat die toepassingsveld van bemarking uitgebrei moet word om nie-wins ondernemings in te sluit. Individue, idees en dienste kan ook bemark word, was hul redenasie.

Soos wat verwag kon word is Kotler \& Levey (1969) se mening nie universieel aanvaar nie. Luck (1969) het byvoorbeeld so ' $n$ benadering as te breed beskou en daarom nutteloos. Sy uitgangspunt was dat die fokus van bemarking die handelstransaksie (koop en verkoop) moet wees. Nie-wins ondernemings is dus, volgens Luck (1969), per definisie, uitgesluit van die toepassingsveld van bemarking.

In die daaropvolgende jare het bemarking inderdaad weg beweeg van die vroeëre eng definisie, deur sy invloedsfeer na nie-wins bemarking, die bemarking van dienste en sosiale bemarking uit te brei.

Daar word dikwels beweer dat nie-wins ondernemings soortgelyke geleenthede en bedreigings as privaatsektor ondernemings trotseer - maar dat hulle ook met unieke uitdagings te kampe het.

Hierdie artikel analiseer die toepaslikheid van bemarking en bemarkingspraktyke in 'n nie-wins instelling, naamlik die Suid-Afrikaanse Weermag.

\section{BEMARKING IS ‘N RUILPROSES}

Bemarking is die menslike aktiwiteit wat daarop gerig is om behoeftes en begeertes deur rulprosesse te bevredig (Kotler, 1986: 4). McDonald (1990:1) som die sentrale doel van bemarking op as "... a matching between a company's capabilities and the wants of customers in order to achieve the objectives of both parties." Bemarking is dus in wese daarop ingestel om, deur middel van ' $n$ ruilproses, behoeftes en begeertes te bevredig.

In die daaglikse handelsverkeer vergestalt hierdie ruilproses homself in die vorm van 'n koop/verkooptransaksie. In ruil vir sy geld ontvang die verbruiker ' $n$ produk of diens met bepaalde eienskappe en voordele. Die vernaamste voordele wat die verbruiker of gemeenskap ontvang in sy "transaksie" met die Weermag is vrede, stabiliteit, orde, geregtigheid, 'n toekomswaarborg, ensomeer. As teenprestasie ontvang die Weermag die samewerking, vertroue, lojaliteit en ondersteuning van die gemeenskap, en uiteindelik ' $n$ meer stabiele gemeenskap, vry van onnodige konflikpotensiaal.

Beide partye (die Weermag en gemeenskap) vind dus baat by hierdie "transaksie". Dit is inderdaad 'n belangrike voorvereiste vir effektiewe bemarking.

Diagramaties word die ruilproses soos volg voorgestel: 
DIAGRAM 1 : DIE RUILPROSES IN BEMARKING

DIE OMGEWING

WEERMAG SE VERMOËNS + TAAK
PROSES VAN

AANPASSING

DIE OMGEWING

Bron :Aangepas uit MCDONALD, M.H.B. 1990. Marketing plans : how to prepare them, how to use them. Oxford: Heinemann.

\subsection{DIE BEMARKINGSKONSEP}

Die bemarkingsgerigte onderneming se aktiwiteite word deur die sogenaamde bemarkingskonsep gerig. Hierdie konsep word ondersteun deur vier pilare of elemente, naamlik:

(i) 'n Verbruiker- of kliëntoriëntasie

(ii) 'n Geïntegreerde benadering

(iii) Winsgewendheid

(iv) Sosiale verantwoordelikheid.

Diagram 2 is ' $n$ diagramatiese voorstelling van die verwantskap tussen die bemarkingskonsep en sy onderliggende elemente. aanbieding (produk/diens) om hierdie behoefte te bevredig. In ' $n$ Weermag sou ' $n$ ware bemarkingsgerigte benadering dus vereis dat die gemeenskap se behoeftes bepaal word, en dat ' $n$ produk(te) dan ontwikkel word om hierdie behoeftes te bevredig. ' $n$ Volledige ondersoek van die gemeenskap se behoeftes, en hoe hul die rol van die Weermag sien, sou dus gedoen moes word. Twee argumente kan teen so 'n beskouing ingebring word naamlik (i) dat die Weermag volgens Wet ' $n$ bepaalde taak het om te vervul en (ii) dat die gemeenskap se behoeftes irrelevant is, aangesien die Weermag se taak en verantwoordelikheid in die Verdedi-

\section{DIAGRAM 2 : DIE BEMARKINGSKONSEP}

\begin{tabular}{|c|c|c|c|c|c|}
\hline \multicolumn{5}{|c|}{ DIE BEMARKINGSKONSEP } & \\
\hline & & & & & \\
\hline
\end{tabular}

Bron :Aangepas uit MYERS, J.H. 1986. Marketing. New York: McGraw-Hill : 15.

Die implikasie van 'n bemarkingsbenadering vir Weermag besluitneming word vervolgens bespreek.

\subsubsection{VERBRUIKERSORIËNTASIE}

'n Ware bemarkingsgeoriënteerde benadering begin by die identifisering van die verbruiker se behoeftes. Die onderneming ontwikkel dan ' $n$ bemarkings- gingswet omskryf word. So 'n argument is nie heeltemal verkeerd nie, want in die bemarkingsproses is daar immers twee partye: die sogenaamde verbruiker en die produk- of diensverskaffer. Die taak van die bemarker is om die behoeftes van die verbruiker te bepaal en te bevredig, maar nie ten koste van sy eie onderneming nie. Die Weermag hoef dus nie agteroor te buig om sy 
verbruiker tevrede te stel ten koste van die doelwitte wat hy nastreef nie. 'n Balans tussen die behoeftes van die gemeenskap en die van die Weermag is dus wenslik.

'n Goeie voorbeeld van 'n verbruikersoriëntasie is die Verkeerspolisie wat vroeë môre en laatmiddag verkeer reguleer op die besigste paaie. Hoewel hulle gedurende hierdie tye nie in staat is om verkeersoortreders vas te vat nie (en dus nie ' $n$ bydrae tot die inkomste van die Stadsraad maak nie), vervul hulle ' $n$ belangrike voorkomende rol. In die proses word die belange van die verkeerspubliek voorop gestel, en deur voorkomend op te tree, vermy hulle onnodige werk as gevolg van ongelukke, ensomeer.

\subsubsection{GEÏNTEGREERDE BENADERING}

Die tweede gedagte wat die bemarkingskonsep onderlê is ' $n$ geïntegreerde benadering. Hierdie benadering impliseer die volgende:

(a) Die fokus op die verbruiker moet alle bemarkingsbesluite van die onderneming se bemarkingsafdeling penetreer.

(b) Die idee van ' $n$ verbruikersoriëntasie moet na alle organisatoriese vlakke en posisies van die onderneming deurgegee word.

(c) 'n Sisteembenadering word voorgestel om al die eenhede van die onderneming wat met verbruikersbevrediging te make het, saam te snoer.

Toegepas op die besondere omstandighede van die Weermag beteken dit gewoon dat elke lid van die span, hetsy generaal of manskap, hierdie verbruikers- of gemeenskapsfilosofie moet nastreef. Enige swak skakel in die diensketting laat die hele poging om gemeenskapsgerig te wees, in duie stort.

Hoewel die Weermag nie ' $n$ bemarkingsafdeling het nie (daar is wel 'n Skakelafdeling), is elke lid in uniform ' $n$ beelddraer van die S.A. Weermag. In 'n gemeenskap waar daar antagonisme of selfs haat jeens die Weermag bestaan, word die positiewe optrede van elke individu ' $n$ uiters belangrike instrument wat sukses of mislukking bepaal. Die teenoorgestelde is natuurlik ook waar: enige negatiewe optrede van ' $n$ lid in uniform doen afbreuk aan die beeld en geloofwaardigheid van die Weermag.

\subsubsection{WINSGEWENDHEID}

Hoewel die S.A. Weermag nie wins najaag of ' $n$ produk of diens verkoop nie, word vereis dat Staatsgeld omsigtig spandeer word. Die ekonomiteitsbeginsel, dit wil sê om die hoogs moontlike behoeftebevrediging met die aanwending van relatief skaars hulpmiddele te verkry, bly steeds ' $n$ doelwit. Dit is immers die belastingbetaler se geld wat gebruik word om die Weermag te finansier.

\subsubsection{SOSIALE VERANTWOORDELIKHEID}

Waar die tradisionele bemarkingsbenadering slegs die bevrediging van verbruikersbehoeftes nagejaag het, het die kontemporêre benadering ' $n$ breër beskouing. Dit stel as uitgangspunt die verbruiker en gemeenskap se belange voorop.

Enige aksie of poging wat die belange van die gemeenskap skaad of benadeel word as onverantwoordelik en egosentries beskou. Toegepas op die Weermag se omstandighede beteken dit dat alle optredes en projekte onderneem moet word met inagneming van die invloed wat dit op die gemeenskap het. Die voortdurende bestryding van geweld en intimidasie met instutisionele geweld kan ' $n$ geweldskultuur op die langtermyn tot gevolg hê. So 'n kultuur sou die taak van die Weermag, veral op die langtermyn, bemoeilik. Sulke optrede is sekerlik nie in die belang van die gemeenskap nie.

\subsubsection{SAMEVATTING}

Daar word van die bemarkingsgerigte Weermag vereis om:

(a) Deurgaans ingestel te wees op die behoeftes en nood van die gemeenskap aan wie ' $n$ diens gelewer word. 
(b) 'n Geïntegreerde benadering te volg en te verseker dat elke lid van die span bewus gemaak word van sy taak en verantwoordelikheid.

(c) Die hoogs moontlike behoeftebevrediging te bereik met die aanwending van skaars hulpbronne (geld, mannekrag, tyd).

(d) Die welvaart (materieël en geestelik) van die gemeenskap te probeer verhoog met hul optrede en interaksie met individue en groepe.

\section{STRATEGIESE BEMARKING}

Die Weermag funksioneer, net soos enige onderneming, in 'n dinamiesveranderende omgewing. Hierdie eksterne omgewing oefen ' $n$ belangrike invloed op die Weermag uit. Die doel met strategiese bemarkingsbeplanning is om ' $n$ strategiese brug tussen die onderneming/Weermag se hulpbronne en die snel veranderende eksterne omgewing te bewerkstellig.

Twee fases word in die strategiese bemarkingsbeplanningsproses onderskei; naamlik

(a) 'n hulpbronontleding waartydens die interne hulpbronne, sterkpunte en swakpunte van die instelling ontleed word en:

(b) 'n omgewingsontleding wat ' $n$ ontleding van die eksterne omgewing en die geleenthede en bedreigings wat dit bied, behels.

Hierdie ontleding, waarna kortweg as 'n "SWOT-analise" (SWOT = strengths, weaknesses, opportunities, threats) verwys word, kan diagramaties soos volg voorgestel word:
Voortspruitend uit die SWOT-analise formuleer die instelling ' $n$ missie, en oorhoofse bemarkingsdoelwitte en beleid. In diagram 4 word 'n voorstelling hiervan gegee. Hieruit kan gesien word dat vier spesifieke, strategiese vrae in die proses beantwoord moet word, naamlik:

(i) Waar is ons nou?

(ii) Waarheen behoort ons te gaan?

(iii) Waarheen wil ons gaan?

(iv) Hoe kom ons daar? Het ons die nodige/vereiste hulpbronne?

DIAGRAM 4 : DIE STRATEGIESE BEMARKINGSBEPLANNINGSPROSES

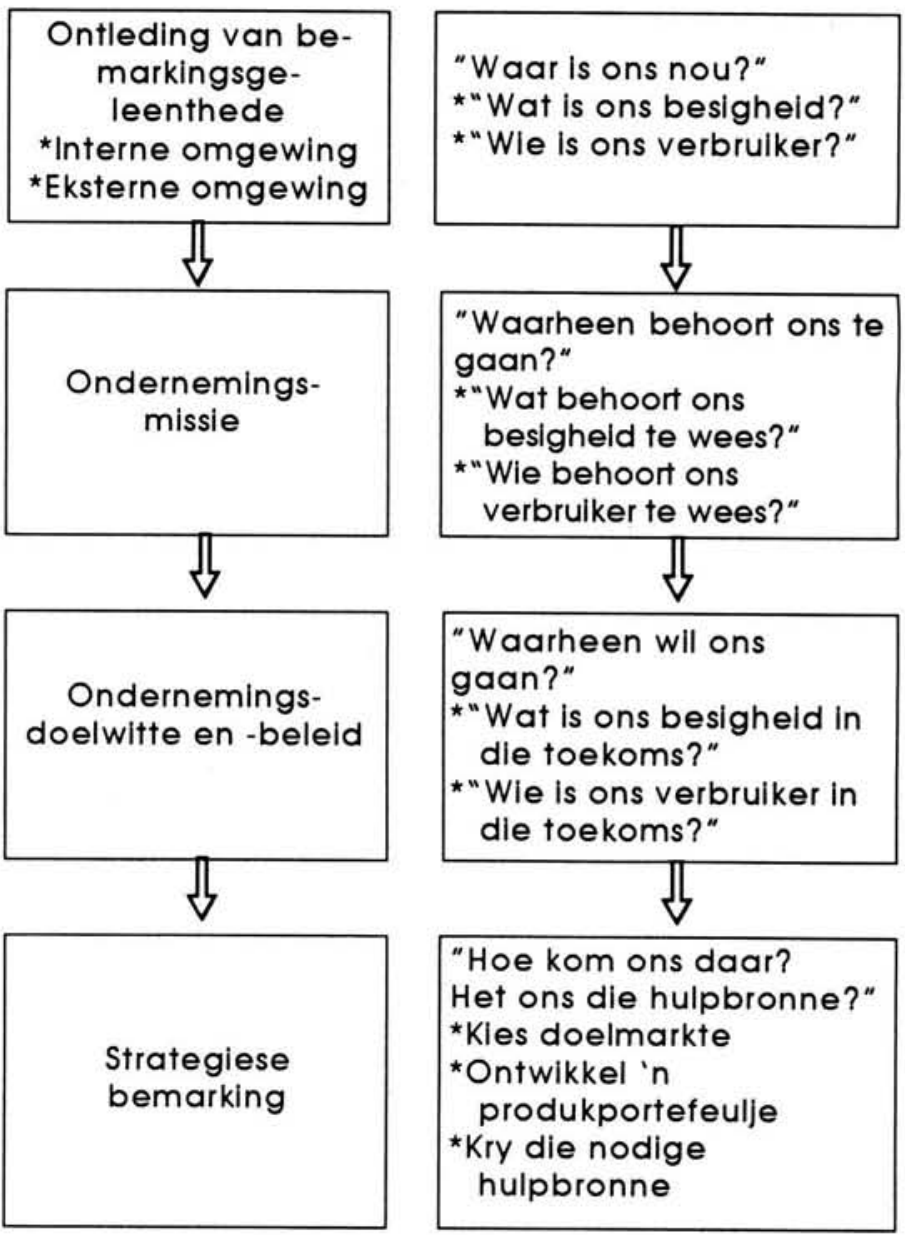

Bron:Aangepas uit LUCAS, G.H.G.(Red)

DIAGRAM 3 : DIE SWOT-ANALISE

STERKPUNTE

SWAKPUNTE

Ontleding van die interne hulpbronne van die instelling (bv. personeel; finansies; bestuurskundigheid; toerusting)

Ontleding van die eksterne omgewing wat ' $n$ invloed op die instelling uitoefen (bv. politieke omgewing; ekonomiese omgewing;

tegnologiese omgewing; sosiale omgewing; mededingende omgewing) 
1983. Dle taak van die bemarkingsbestuur. Pretoria: J.L. van Schaik : 578.

'n Onderneming, en dus ook die Weermag, se mededingende vermoë, of kans op sukses, sal grootliks bepaal word deur sy vermoë om, met behulp van sy sterkpunte, die bedreigings in die eksterne omgewing hok te slaan, en die geleenthede te benut (Marketing Mix, Maart $1990: 57$ ).

\subsection{DIE BENUTTING VAN BEMARKINGSGELEENTHEDE}

Die effektiewe benutting van bemarkingsgeleenthede kan sukses of mislukking in die eksterne omgewing bepaal. Lucas (1983 : 580-581) identifiseer vier moontlike bemarkingsgeleenthede, naamlik markindringing, markontwikkeling, produkontwikkeling en diversifikasie. Diagram 5 toon dat geleenthede vir bestaande en nuwe produkte sowel as bestaande en nuwe markte geïdentifiseer kan word.

DIAGRAM 5 : SOORTE BEMARKINGSGELEENTHEDE

\begin{tabular}{c|c|c|}
\multicolumn{1}{c}{} & \multicolumn{1}{c}{ HUIDIGE PRODUKTE } & \multicolumn{1}{c}{ NUWE PRODUKTE } \\
\cline { 2 - 3 } $\begin{array}{c}\text { HUIDIGE } \\
\text { MARKTE }\end{array}$ & MARKINDRINGING & PRODUKONTWIKKELING \\
\cline { 2 - 3 } $\begin{array}{c}\text { NUWE } \\
\text { MARKTE }\end{array}$ & MARKONTWIKKELING & DIVERSIFIKASIE \\
\cline { 2 - 3 } & &
\end{tabular}

Bron:Aangepas uit LUCAS, G.H.G. (Red) 1983. Die taak van dle bemarkingsbestuur. Pretoria: J.L. van Schaik : 580.
Produkontwlkkellng behels die ontwikkeling van nuwe of verbeterde produkte/projekte vir huidige markte. Die Weermag wil dus die behoeftes van die huidige markte meer doeltreffend bevredig deur nuwe produkte/projekte te ontwikkel of deur bestaandes te verbeter.

Diversifikasle vind plaas indien die Weermag kan besluit om nuwe produk/ projek- en markgebiede te betree, wat moontlik totaal vreemd aan hom is. Die besluit om te diversifiseer mag die resultaat van ' $n$ herwaardering deur die beveltopstruktuur wees. ' $n$ Voorbeeld sou dus wees om klinieke in swart konflikgebiede te opereer of om vullisverwydering te doen waar munisipale dienste opgeskort is. Opleiding van die algemene publiek in aspekte soos selfverdediging, skietkuns en noodhulp is verdere voorbeelde van so ' $n$ strategie.

\subsection{MISSIEFORMULERING}

Dit is noodsaaklik dat die bemarkingsgerigte instelling ' $n$ missie formuleer, soos wat Kotler (1986: 59) tereg beweer: "A well-worked-out mission statement provides corporate personnel with a shared sense of opportunity, direction, significance and achievement. The company mission statement acts as an 'invisible hand' that guides widely dispersed employees so that they can work independently and yet collectively toward realizing the organization's potential."
Toegepas op die Weermagsituasie kan diagram 5 soos volg geînterpreteer word:

Markindringing: mag beteken dat die Weermag poog om sy beeld in die gemeenskap te verbeter deur huidige produkte/projekte in die huidige markte (gemeenskap) deur middel van 'n meer aggresiewe bemarkingstrategie te "verkoop".

Markontwikkeling vind plaas wanneer die Weermag sy aansien wil verhoog deur sy huidige produkte/projekte op nuwe markte te konsentreer (in plaas van die jeug, die ouer gemeenskap).
Weermageenhede en -personeel wat verwyderd en geïsoleerd van mekaar opereer, kan dus saamgesnoer word deur ' $n$ oo'koepelende missiestelling.

Vrae wat in die proses van missieformulering beantwoord moet word, sluit die volgende in:

* Wat is ons besigheid/taak?

* Wie is ons verbruiker?

* Wat is waarde vir die verbruiker?

* Wat sal ons besigheid/taak wees?

* Wat behoort ons besigheid/taak te wees? (Kotler, 1986:59)

Kritiese besinning oor hierdie vrae kan tot nuwe insigte lei, en indien die 
Weermag toekomstige aksies hierop baseer kan daarin geslaag word om 'n gunstige beeld uit te dra. Kritici mag meen dat die taak van die Weermag deeglik in die Verdedigingswet omskryf word, en dat ' $n$ missie oorbodig mag wees. Die vraag is egter: "Wie lees die Verdedigingswet?" Vir baie dienspligtiges en staandemaglede beteken die Wet niks, dit is ' $n$ komplekse, lywige en niksseggende dokument wat vir hulle geen waarde het nie. Indien ' $n$ missie uit die Wet aflei kan word, wat die vrae wat hierbo vermeld is ook aanspreek, kan dit meehelp om lede saam te snoer tot die bereiking van geformuleerde doelwitte.

Dit is belangrik dat, by die omskrywing van die besigheid/taak van die Weermag, drie dimensies aangespreek moet word, naamlik:

\section{* WIE? - die verbruikersgroepe} wat bedien sal word.

* WAT? - die verbruikersbehoeftes wat bevredig sal word.

* HOE? - die tegnologie wat gebruik sal word om die behoeftes te bevredig.

\subsection{FORMULERING VAN DOELWITTE EN -BELEID}

Nadat die eksterne omgewing ontleed en die missie van die instelling geformuleer is, word die doelwitte en beleid neergelê.

Die doelwitte wat nagestreef word is ' $n$ logiese uitvloeisel van die veranderinge in die eksterne omgewing asook die hersiening van die missie van die instelling.

Op hierdie terrein moet die militaris, met inagneming van die voorafgaande, besluit watter doelwitte nagestreef moet word, aangesien die onderneming se doelwitte hoofsaaklik op winsgewendheid, markaandeel, omset, innovasie of risikodiversifisering betrekking het (Marketing Mix, Maart 1990: 60).

\subsection{SAMEVATTING}

In die voorgaande afdeling is aangetoon dat strategiese bemarkingsbeplanning daarop ingestel is om ' $n$ strategiese brug tussen die dinamiese eksterne omgewing en die hulpbronne van die instelling te bewerkstellig. In die proses moet die militêre strateeg optimaal kapitaliseer op die geleenthede in die eksterne omgewing, waar vier hoofstrategieë gevolg kan word.

Die Weermag sal ook vir 'n oomblik moet nadink oor sy missie, en spesifieke vrae soos "Wie is ons verbruiker?", "Wat is waarde vir die verbruiker?", en "Wat behoort ons taak te wees?" sal beantwoord moet word. Voortspruitend hieruit moet spesifieke strategiese doelwitte en breë beleidsriglyne geformuleer word.

Voortspruitend uit die strategiese bemarkingsbeplanningsproses, word gedetailleerde funksionele/taktiese bemarkingstrategieë ontwikkel.

\section{FUNKSIONELE/TAKTIESE BEMARKINGSBEPLANNING}

Voortspruitend uit die bemarkingskonsep blyk dit dat bemarking begin met die identifisering van ' $n$ verbruikersbehoefte en eindig met die lewering van ' $n$ produk/diens wat die behoefte bevredig. Taktiese bemarkingsbeplanning begin dus met die soeke na ' $n$ aantreklike bemarkingsgeleentheid. Diagram 6 toon ' $n$ volledige uiteensetting van die bemarkingsbeplanningsproses, wat kulmineer in ' $n$ bemarkingstrategie, wat uit 'n kombinasie van 'n produk-, prys-, promosieen distribusiestrategie en die doelmark bestaan.

\subsection{VIND AANTREKLIKE BEMARKINGSGELEENTHEDE}

Die aanvang van die bemarkingsbeplanningsproses behels eerstens ' $n$ ontleding van bemarkinsgeleenthede in en buite die instelling en tweedens ' $n$ waardebepaling van die instelling se vermoë om hierdie geleenthede te benut (Lucas, 1983 : 38-39).

Hierdie stap sluit aan by die SWOTanalise wat:

(a) daarop ingestel is om die sterken swakpunte van die instelling te bepaal en 


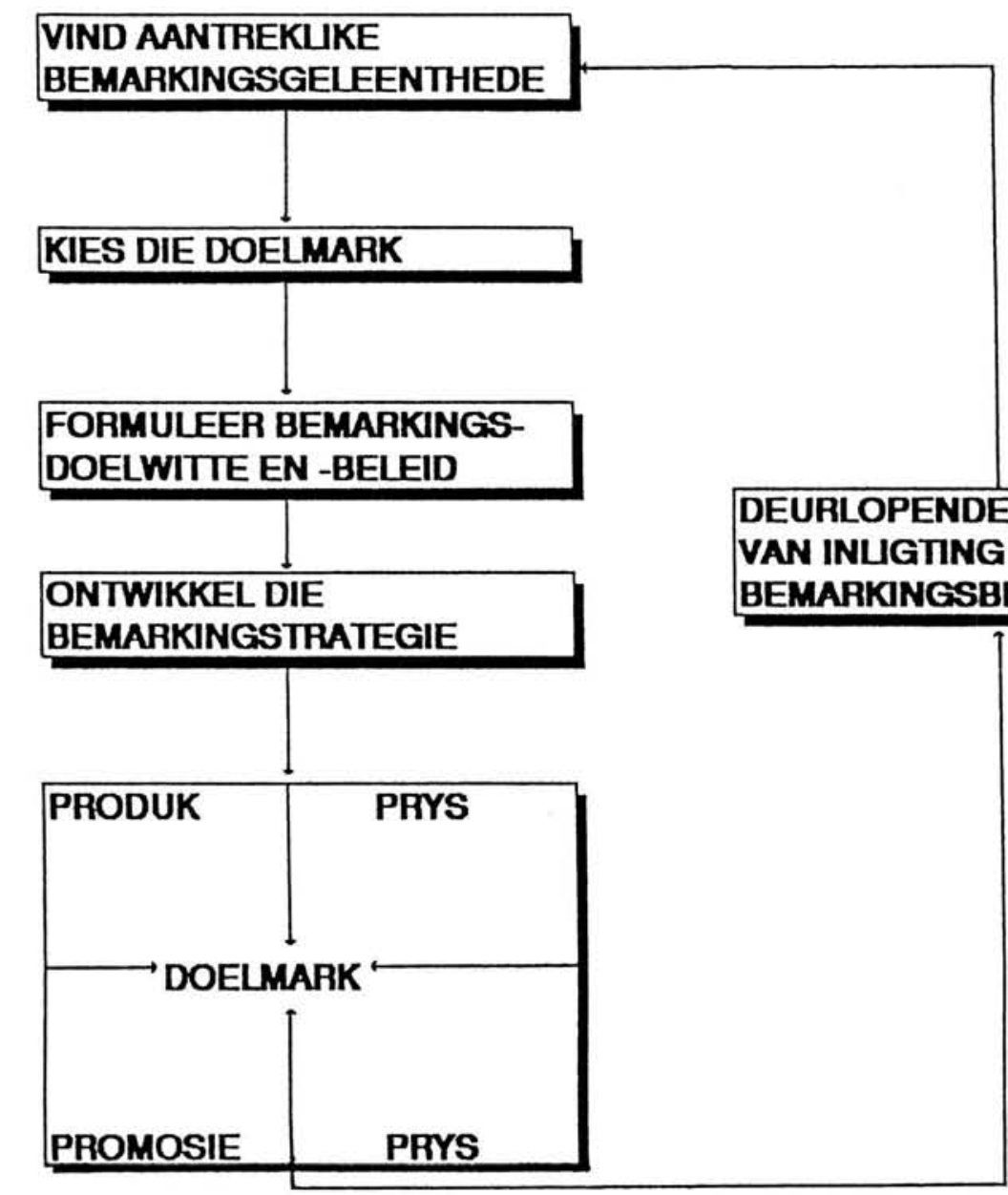

Bron:Aangepas uit LUCAS, G.H.G. (Red) 1983. Die taak van die bemarkingsbestuur. Pretoria : J.L. van Schaik :38.

(b) 'n ontleding van die eksterne omgewingsfaktore behels.

Die Weermag sou dus, tydens hierdie stap, soek na projekte wat hulle kan aanpak om die behoeftes in die mark/ gemeenskap te bevredig. In die proses word die Weermag se vermoë om hierdie geleenthede te benut, ook in oënskou geneem. Vrae wat gevra moet word sluit in:

* "Watter veranderinge in die eksterne omgewing beïnvloed ons?"

* "Beskik ons oor die hulpbronne?" (mense, vaardighede, finansies, ens.)

\subsection{KIES DIE DOELMARK}

Nadat ' $n$ bemarkingsgeleentheid geïdentifiseer is, kies die instelling ' $n$ doelmark waarop die bemarkingspo- ging gerig gaan word. 'n Doelmark word omskryf as 'n min of meer homogene groep verbruikers (mense) aan wie ' $n$ bemarkingsaanbieding gerig word (Lucas, $1983: 39$ ).

Ten einde vermorsing en oneffektiewe bemarking te vermy, word die instelling se produk/diens op 'n spesifieke doelmark gerig. Dit is daarom noodsaaklik dat enige projek van die Weermag, op ' $n$ vooraf gedefinieërde doelmark gerig word. Wanneer daarop besluit word om die beeld van die Weermag te verbeter, moet daar besluit word onder watter groep mense dit gedoen wil word, byvoorbeeld skoliere in ' $n$ sekere gebied; of moeders in ' $n$ sekere area.

Wanneer daar dus gepoog word om 'n bepaalde doelwit te bereik, moet daar besef word dat nie alle groepe mense 
op dieselfde wyse bereik kan word nie. Terwyl een groep deur middel van 'n sportbyeenkoms bereik kan word, kan ' $n$ ander groep se welwillendheid deur middel van 'n kliniekprojek beïnvloed word. Die doelmark se unieke behoeftes moet dus verreken word, en met die beoogde doelwit versoen word.

\subsection{FORMULEER \\ BEMARKINGSDOELWITTE EN BELEID}

Nadat ' $n$ doelmark gekies is, word bemarkingsdoelwitte geformuleer. Vrae wat tydens die missieformulering gevra en beantwoord is, kan as riglyne gebruik word tydens hierdie stap.

Net soos tydens die formulering van strategiese doelwitte (sien afdeling 3.3 ) aangedui is, moet die militêre strateeg self besluit watter doelwitte hy in besonder wil nastreef.

Tydens hierdie stap word breë bemarkingsriglyne ook neergelê. Dit vloei uit die breër beleid van die instelling voort, en het betrekking op die riglyne wat neergelê word vir die beplanning en uitvoering van en beheer oor die bemarkingstrategie op alle vlakke in die organisasie.

\subsection{ONTWIKKEL DIE BEMARKINGSTRATEGIE}

Laastens word 'n bemarkingstrategie ontwikkel. Dit verwys na die bemarkingsplan waarmee bemarkingsbestuur in die omgewing meeding om die organisasie- en bemarkingsdoelwitte te verwesentlik. In hoofsaak bestaan dit uit twee onafhanklike, dog interverwante komponente, naamlik:

* 'n Doelmark - die min of meer homogene groep verbruikers aan wie die produk bemark word en

* 'n Bemarkingsresep - die kombinasie beheerbare bemarkingsveranderlikes, naamlik produk, prys, promosie en distribusie wat aangewend word om die doelmark te bevredig.

Hierdie elemente van die bemarkingsresep is:
Produk - verwys na die ontwikkeling van behoeftebevredigende nuttighede vir die doelmark. Die produk is dus in wese die draer van bevrediging, of die voordeel wat dit vir die verbruiker of ontvanger daarvan inhou.

Distribusie - het te make met die oordra van die behoeftebevredigende produk na die doelmark, waar, wanneer $e n$ in die hoeveelhede waarin die verbruiker dit verlang.

Promosle - verwys na die bekendstelling van die behoeftebevredigende produk aan die doelmark en die skepping van verbruikersvraag.

Prys - verwys na die prys wat die verbruiker bereid is om vir sy behoeftebevrediging te betaal en die prys waarteen die organisasie bereid is om die produk te verskaf (Lucas, $1983: 45)$.

Voorgenoemde elemente kan deur die organisasie gemanupileer word ten einde die behoeftes van die doelmark te bevredig. Maar wat bepaal of die verbruiker se behoeftes bevredig word al dan nie?

\section{VERBRUIKERSTEVREDENHEID: WAT IS DIT EN WAT BEPAAL DIT?}

Wanneer verbruikers ' $n$ transaksie met 'n onderneming aangaan, het hulle bepaalde verwagtinge ten opsigte van aspekte soos diens, produkkwaliteit, prys, ensomeer. Indien die onderneming hierdie verwagtinge bevredig of oortref, is die verbruiker normaalweg tevrede. Indien dit nie bevredig word nie, lei dit tot verbruikersontevredenheid. Hierdie beginsel is deur Grönroos (1989) gebruik om ' $n$ dienskwaliteitmodel te konstrueer (soos uiteengesit in diagram 7) wat primêr daarop gemik was om aan te toon hoe verbruikers persepsies van diensgehalte vorm.

\subsection{VERWAGTE DIENS EN WAARGENOME DIENS}

Tradisionele bemarkingsaktiwiteite van die onderneming, asook die verbruiker se vorige ervaring met die onderne- 


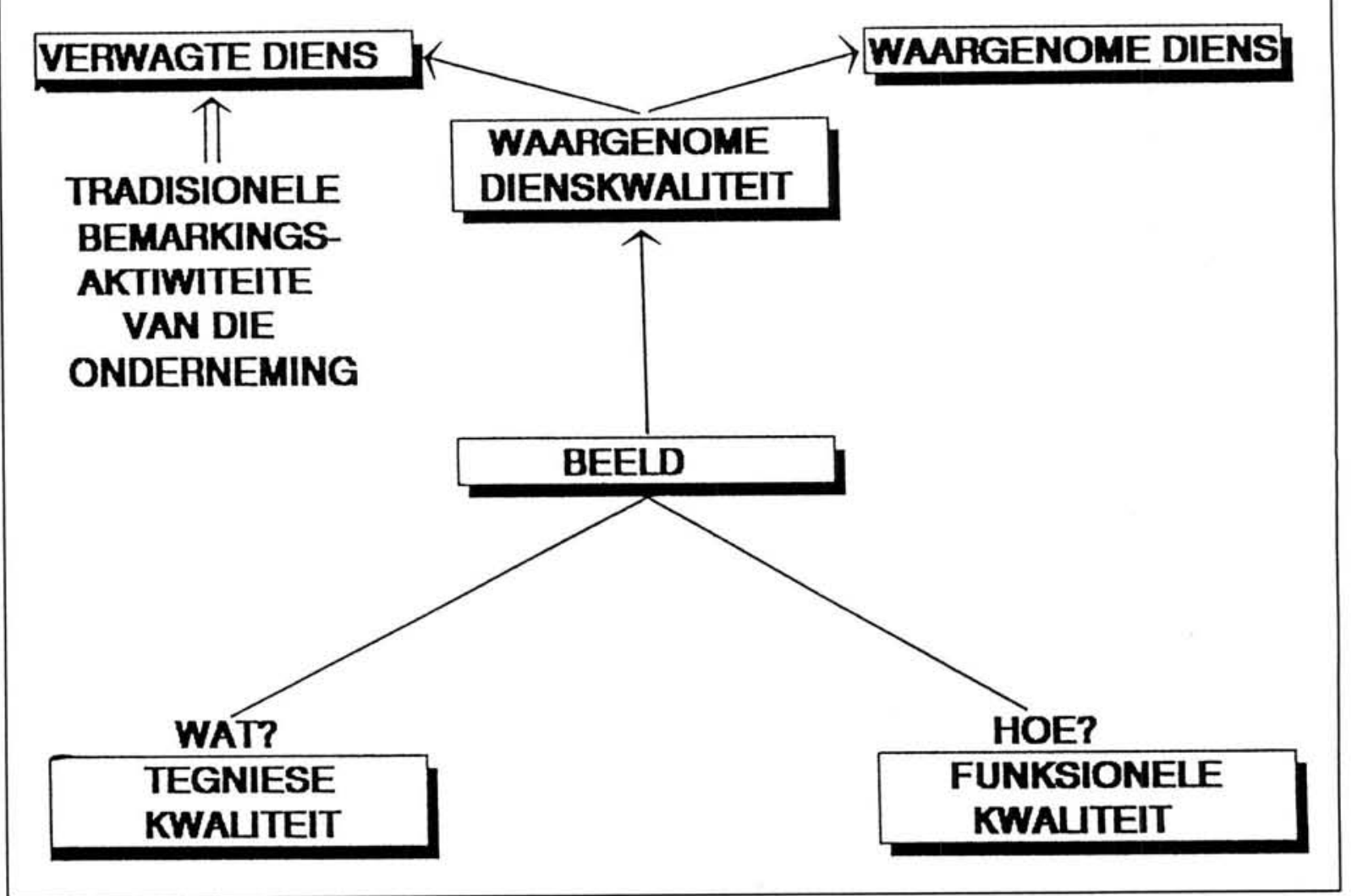

Bron: Aangepas uit GRöNROOS, C., 1989. Strategic management and marketing in the service sector. Sweden : Chartwell-Bratt : 41.

ming, gee aanleiding tot sekere verwagtinge aan die kant van die verbruiker. Waargenome diens aan die ander kant verwys na die verbruiker se werklike belewenis/ervaring (persepsie) van die diens wat gelewer word.

Die verskil tussen die verwagte diens en waargenome werklike diens, is die waargenome dienskwaliteit. Drie moontlikhede is dus moontlik:

Verwagte diens = Waargenome diens Verwagte diens > Waargenome diens Verwagte diens < Waargenome diens.

Wanneer waargenome diens die verwagte diens oortref of min of meer gelyk is, is die verbruiker geneig om tevrede te wees. Wanneer verwagte diens egter groter is as die waargenome diens, is die verbruiker egter geneig om ontevrede te wees.

Die implikasie vir ' $n$ positiewe beeld en verbruikerstevredenheid is duidelik: die Weermag moet daarna streef om die verwagtinge van die gemeenskap wat hulle dien, te oortref. Waar daar negatiewe persepsies of ervaringe onder die bevolking voorkom, is dit moeiliker en sal die proses langer neem. Doelgerigte aksie wat daarop ingestel is om die lewenskwaliteit van die gemeenskap in die breë te verbeter, met inagneming van die behoeftes van die Weermag, is dus noodsaaklik.

\subsection{TEGNIESE KWALITEIT EN FUNKSIONELE KWALITEIT}

Volgens Grönroos (1989: 38-39) is daar veral twee faktore wat dienskwaliteit bepaal, naamlik tegniese kwaliteit en funksionele kwaliteit. Tegniese kwaliteit verwys na "WAT" die verbruiker ontvang tydens sy interaksie met die onderneming, dus die produk of diens. Hierdie "WAT" is uiteraard belangrik vir die verbruiker. Toegepas op die Weermag mag dit verwys na stabiliteit wat verskaf word, kliniekdienste wat gelewer word, ensomeer.

Verbruikers is egter nie slegs tevrede met WAT hulle van die onderneming ontvang nie, maar ook "HOE" die diens 
gelewer word. Die houding, liggaamstaal, vriendelikheid, hulpvaardigheid, voorkoms, ensomeer van die diensleweraar bepaal HOE die diens gelewer word. Die houding van personeel is dus van groot belang. Tydens manskappe se optrede en handelinge in die gemeenskap, is WAT hulle doen net so belangrik as HOE hulle dit doen.

Die funksionele kwaliteitsdimensie kan nie so objektief waargeneem word as die tegniese kwaliteitsdimensie nie, wat dienslewering ' $n$ uiters gekompliseerde aktiwiteit maak.

\subsection{BEELD AS KWALITEITSDIMENSIE}

Afgesien van tegniese en funksionele kwaliteit, speel die beeld van die onderneming ' $n$ belangrike rol wanneer waargenome dienskwaliteit gevorm word.

Elke onderneming en instelling het 'n beeld wat na buite geprojekteer word. Volgens Grönroos (1989: 40) is hierdie beeld die resultaat van hoofsaaklik twee tipes faktore:

(a) Eksterne faktore, soos tradisies, ideologieë en mondelinge mededelings en

(b) Tradisionele bemarkingsaktiwiteite van die onderneming (soos promosie, pryse, openbare betrekkinge, ensomeer).

Tradisionele bemarkingsaktiwiteite, mondelinge mededelings asook tegniese en funksionele kwaliteit toon ' $n$ sterk interafhanklikheid. So byvoorbeeld beweer Grönroos (1989: 41) dat alle tradisionele bemarkingsaktiwiteite, insluitende korporatiewe beeldbouadvertensies ' $n$ invloed op verbruikersverwagtinge uitoefen. ' $n$ Advertensieveldtog wat die indruk skep dat tegniese- en funksionele kwaliteit beter is as wat dit in werklikheid is, sal dus tot hoër verbruikersverwagtinge aanleiding gee. Indien die waargenome diens egter dieselfde bly, raak die gaping tussen verwagte- en waargenome diens steeds groter. Dit sal tot verbruikersontevredenheid aanleiding gee, wat verder vererger sal word deur negatiewe mondelinge mededelings deur ontevrede verbruikers. Die resultaat is ' $n$ instelling met ' $n$ swak en ongeloofwaardige beeld.

Wanneer die Weermag dus besluit om ' $n$ aggresiewe bemarkingsveldtog te onderneem (wat gebaseer is op die behoeftes van die gemeenskap) ten einde sy beeld te verbeter, moet dit gepaard gaan met ' $n$ verbetering in beide tegniese- en funksionele kwaliteit. Dit sal lei tot ' $n$ verhoging in die waargenome dienskwaliteit, wat weer groter verbruikerstevredenheid sal meebring.

\subsection{SAMEVATTING}

Die riglyne wat ' $n$ verbruikersingestelde Weermag behoort na te volg kan dus soos volg opgesom word:

* Indien die Weermag die hart van die gemeenskap wil wen, moet hulle daarna streef om aan die verwagtinge van die gemeenskap te voldoen of selfs poog om dit te oortref.

* WAT die gemeenskap van die Weermag kry, is net so belangrik as HOE dit aan hulle gelewer word.

* Die beeld van die Weermag kan slegs verbeter word indien elke lid van die span meewerk om dit te doen.

* Om te verkondig dat die Weermag ' $n$ nuwe benadering openbaar sonder dat hul dade dieselfde boodskap uitdra, is ' $n$ futiele oefening.

* Wanneer ' $n$ nuwe benadering nagestreef word; en dit met werklike optrede gedemonstreer word, moet dit aan die gemeenskap gekommunikeer word.

\section{SLOT}

In hierdie artikel is sekere basiese bemarkingskonsepte gedefinieër en op die militêre omgewing van toepassing gemaak. Daaruit blyk dit dat die militêre strateeg bemarking inderdaad kan inspan in die uitvoering van sy 
daaglikse pligte. Die toepassingsmoontlikhede van bemariking is dus inderdaad oneindig; die grense waarvan slegs bepaal word deur die oorspronkliheid en kreatiwiteit van die moderne bemarker.

* Belde professore J.A. Bennet en C. Boshoff is verbonde aan die Departement Bedryfsekonomie, Universitelt VISTA.

\section{VERWYSINGS}

GRÖNROOS, C. 1989. Strategic management and marketing in the service sector. Sweden : Chartwell-Bratt.

KOTLER, P. 1986. Principles of marketing. Englewood Cliffs, New Jersey : Prentice-Hall.

KOTLER, P. \& LEVEY, S.J. 1969. Broadening the Concept of Marketing. Journal of Marketing. vol. 33 : 10-15.

LUCAS, G.H.G. 1983. Die taak van die bemarkingsbestuur. Pretoria : J.L. van Schaik (Pły.) Ltd.

LUCK, D.J.1969. Broadening the Concept of Marketing - Too Far. Journal of Marketing, vol. 33:53-54.

MARKETING MIX. 1990. "strategic marketing planning : the decisive point for marketers". March : 56-61.

MCDONALD, M.H.B. 1990. Marketing plans: how to prepare them, how to use them. Oxford: Heinemann Professional Publishing.

MYERS, J.H. 1986. Marketing. New York : McGraw-Hill Book Company. 